\title{
MOLDOVAN DIASPORA'S SOCIAL NETWORKS: POLITICAL MOBILIZATION AND PARTICIPATION
}

\author{
Ciobanu Rodica ${ }^{1}$ and Rosca Mariana ${ }^{2}$
}

DOI: $10.24989 /$ ocg.338.26

\begin{abstract}
In the early 90s, the Republic of Moldova declared its independence and began to build a sovereign state. The state construction was characterized by severe political, economic and social crises that pushed many Moldovans to leave the country and look for a better life abroad. Once settled abroad, many Moldovans kept in contact with their homeland via online platforms. Additionally, they began to create online communities and social networks, and start using them as main tools to inform and share the information, to debate the political situation at home and share some opportunities. Later on, social networks became a place for political mobilization and a source of transnational influence and transfer of innovation back home. Drawing on a qualitative analysis of diaspora's social networks the current article acknowledges their potential to engage and mobilize the political participation of the Moldovan diaspora. Such a practice is an example of active engagement and solidarity with the Moldovans back home and points out the decisive role that Moldovan diaspora can play for the country of origin transformation. Therefore the article concludes that social networks transcended their initial aim and transformed into a space of political mobilization and participation.
\end{abstract}

\section{Introduction}

Nowadays, regardless of the geographical location, he or she can connect, talk, and access a big amount of information online. This opportunity has been of paramount importance for migrants. Being abroad and far away from their families and community, online platforms have become spaces of information, resource exchange [22] and political participation [34]. With a simple click, recently arrived migrants and diaspora can access and distribute social media, can debate the online information, create new media content, can establish and join social networks, and can mobilize and inspire political participation.

Many studies have proved that there is a positive correlation between social media and political participation [3,5,9], nevertheless, how social platforms influence citizen engagement and participation remains unexplored [20]. Additionally, there has been little attention paid to the case study of the Moldovan diaspora political participation. Thus, without testing, if there is any evidence of the positive or negative influence of social networks on Moldovan diaspora mobilization and political participation, as well as diaspora claims and causalities between social networks and political participation remains unclear. Therefore, in this article, we examine one such path of "strong" and "weak" social ties [11] which enable Moldovan diaspora to increase their social capital and to obtain different types of embedded resources in social networks [6,25] and influence political participation [34]. Because social networks possess particular characteristics, we argue that online platforms enable more constructive communication among diaspora with distinct types of ties. Consequently, these

\footnotetext{
${ }^{1}$ Faculty of Journalism and Communication Sciences, Moldova State University, Republic of Moldova

${ }^{2}$ Faculty of Social and Human Sciences, University of Deusto, Spain
} 
social ties facilitate unique routes for engaging in political activities [5]. Specifically, we theoretically suggest that social network sites successfully combines both strong and weak ties in Moldovan diaspora's mobilization and political participation. As a result, social network sites might be more efficient at promoting political engagement by needed reinforcement, as well as might provide optimal premises at sharing and debating political information. Thus, this combination of social ties on social network sites might lead to Moldovan diaspora political mobilization and participation.

Despite of this, few studies have focussed on the influence of different online platforms and online social networks on participatory behaviors [34]. To fill in this research gap, we first start with the literature review on social capital and political participation - that is closely linked to social networks and diaspora. Subsequently, we present the case study of the Moldovan Diaspora social network site. The results reveal the Moldovan diaspora's strong interest in politics back home, and a positive correlation between the social network's engagement and political participation. The link between Moldovan diaspora mobilization and political participation is framed by the social network sites within which diaspora participate and communicate. Additionally, the social networks' power to mobilize the Moldovan diaspora political participation seems to be influenced by the size, heterogeneity, and ties of the diaspora's social network. Therefore, participation might increase within large social networks of like-minded individuals, but might declines inside homogeneous networks that are small in size and consequently have reduced chances to influence and inform about political issues. The final part of the article is dedicated to the significance of these results for the Moldovan diaspora's social networks and political participation.

\section{Theoretical foundation}

\subsection{Social Capital and Migration}

Social capital can be explained as the resources (information, knowledge, ideas, supports) coming from the individuals' relationships in social networks [4,6,31]. Analyzing social capital Bourdieu emphasized the structure and ties of acting individuals in resource accumulation. Later on, Putnam added the community level to the social capital analysis and Coleman emphasized the outcomes of social networks through civic engagement and political participation. Accordingly, the main difference of social capital relies on the complex relationships between individuals and their bonds with communities, networks, or societies that bring material or non-material added value. In this way, individuals have access to resources thanks to their relationships with other individuals, communities, and networks that share some common norms, values, and experiences in a structured field [25,29]. Keles defined it as follows the "social capital refers to the resources (information, knowledge, ideas and various supports) embedded in social networks that individuals procure by virtue of their relationships with other people" [18]. At the same time, Nahapiet and Ghoshal framed the social capital as a set of resources rooted in relationships with three clusters of attributes: structural, relational and cognitive dimensions of social capital, and which, according to the authors, are highly interrelated. The structural attribute outlines the pattern of relationships and networks ties in an organization, and it describes the linkages' density, connectivity, and hierarchy. The relational attribute emphasizes the nature of relationships, where the key values are trust, norms, obligations, expectations, and identifications. While the cognitive attribute outlines the impact of a shared language, code or narratives on reaching a common understanding, interpretation or meaning [27].

In migration studies, social capital becomes relevant due to its contribution to understanding how migrants gain or lose access to resources and participate in the social, economic or political life of their country of origin or destination $[8,24]$. These studies discuss migrants and community 
development as a result of within-group connections (bonding), between-groups connections (bridging) and linking social networks that influence the resources' access and capital return [24,29]. Additionally, these studies argue that social networks of ethnic, cultural, religious, etc. groups represent a powerful tool to enhance social mobility and support to overcome discrimination and marginalization of subordinated individuals and groups, such as diasporas [8].

Diaspora membership in a social network can increase their opportunities to access new information as well as offer opportunities to affiliate participate and as a result, have a direct impact on social status and wellbeing. This cause and effect mechanism means that one can increase their social capital by joining a social network and access additional information, influence, social and political credentials, and reinforcements. In this line, Lin points out that a revolutionary rise of social capital is due to cyber-networks or the internet [25].

Some research brings evidence on the positive contribution of the internet in accumulation and increase of social capital $[13,16]$ as well as its role as a catalyst for civic and political participation $[10,34]$. Diaspora communities, far away from home, establish virtual communities to increases their social capital, and with the socio-political and geographical mobility and the Internet manage to compress time and space, and access multiple online supports [18].

Globally many scholars, from a variety of disciplines, have undergone researches on diaspora's social networks. Some studies focused to understand the diaspora phenomenon regarding the use and consumption of technology and media [1], diaspora's transnational network claims and engagement [22], while others tested the influence of social networks on political behavior [19] and the role of social networks in facilitating protest and social movement organizations [21]. Nevertheless, little attention has been paid to the other diaspora online social networks, such as Moldovan one.

Since the 90s, shortly after the independence and the multiple and crosscutting crises, the migration flows from the Republic of Moldova started and became a phenomenon with huge social, economic and political impacts. Although the migration phenomenon from the Republic of Moldova has been studied broadly considering its economic, social and political aspects, little research has been undertaken on the study of Moldovan diaspora's social networks in general and on diaspora's social networks political mobilization and participation, in particular. Thus, the current article aims to contribute to filling in this gap.

Drawing upon the existent literature, this article considers the social capital framework to analyze the Moldovan diaspora's social networks and test the influence on diaspora mobilization and political participation.

\subsection{Diaspora Social Networks and Political Participation}

Political participation and political talks are fundamental to democracy [17]. Traditionally these talks took place face-to-face or via unilateral channels but during the last decades, a new form of political talks emerged online, where the users could not only hear the political talks but get actively engaged in the debate, share the political information and generate new political talks themselves. Accordingly, they became active actors in political mobilization and participation. The previous research argues that talking about politics, online or offline, helps individuals overcome uncertainty and helps make sense of political information [28]. Such a possibility to clarify the political doubts as well as critically assess the wide range of information online might be vital for the diaspora members. Some empirical research reveals a positive correlation between debates online and political 
engagement offline [12] but the study of the impact of online debates in the case of Moldovan diaspora is almost absent. Additionally, some research points out the complementary role of the online debates and argue that they usually diversify the sources of information $[14,33]$.

\section{Research Question 1: To what extent the Moldovan diaspora online political discourses associate with political participation?}

Discussing Moldovan diaspora's social network characteristics, particularly size, heterogeneity, and social ties can reveal their effect on the levels of political mobilization and participation. Looking at the size of social networks, some researchers argue that membership in larger networks tends to foster political mobilization and participation [9,23]. Consequently, the bigger a network is than more opportunities it offers to encounter other politically active diaspora members, which helps to boost participation [9]. Because social ties can play an important role in framing online communication practices $[5,13,26]$, their characteristics (weak or strong) might have an important influence on whether social networks play a constructive role in political mobilization and participation or jeopardize it. Therefore, it is likely that the benefits of engaging in social networks online for political mobilization and participation might be influenced by social network characteristics.

\section{Research Question 2: To what extent the Moldovan Diaspora Social Networks' characteristic - size, heterogeneity, and social ties - affect political mobilization and participation?}

The above research questions examine the interactions among Moldovan diaspora's social networks on a social network site and test the network influence on diaspora mobilization and political participation.

\section{Research methodology}

To extract, process, and analyze the data from social network sites of Moldovan diaspora analysis related to political mobilization and participation, we used the qualitative research software NVivo 12 Plus. NVivo is a Qualitative Data Analysis (QDA) tool and the computer software package produced by QSR International, and it is a software that can be used to organize, store and retrieve unstructured data. An elaborated book that addresses the NVivo application in research has been elaborated by Jackson and Bazeley, who described how to use NVivo in qualitative research [15]. The authors argue that NVivo can be used to import data from virtually any source and with advanced data management, query, and visualization tools are just other added value that the software brings to the research. Moreover, NVivo's add-on NCapture can extract online data from a variety of social media sources and social network sites, such as Facebook, Twitter, and others. Consequently, it is a tool that fits best into the aims of the current research and will be used to extract the online data and later on analyze it.

The add-on NCapture for NVivo was installed in our browser to download the required information from the Moldovan Diaspora groups on social network sites during 2019. At first, research has been undergone to identify the Moldovan Diaspora social networks. Therefore, by December 2019, there were 124 social networks of Moldovan diaspora established and functioning. Nevertheless, this modest number does not represent the whole picture of Moldovan diaspora groups online, because it does not include the social networks belonging to the Moldovan diaspora NGOs, and the social network sites that lack the word "Moldovan" in the name of the group. Consequently, the real number of Moldovan diaspora social networks is expected to be much higher. An overview of the social networks' discussions on political mobilization revealed some shared and reposted contents from 
another social network site "ADOPTA UN VOTE" (further after AuV). Additionally, this site seems to be the biggest Moldovan diaspora social network and the discussions are predominantly of a political character. Due to this rationale, for the NVivo analyses was selected the social network AuV. It was created in 2016 with the main aim to mobilize diaspora for political participation, counting at the moment of analysis with 79938 members. Seven hundred posts and comments were downloaded by the authors, and the dataset was then imported in NVivo for further analysis ${ }^{3}$. The following steps were performed to classify a comment as political mobilization or action for political participation.

Generally, data extracted from social network sites come out with a lot of meta-data such as the Post ID, the name of the person commenting, the actual text of the post or comment, the date and time the post or comment was made, etc. For this study, only the actual texts of the posts and comments field were used and analyzed. The posts and comments are finally coded into mobilization and political participation clusters by making use of the auto code feature in NVivo12. Examples of political participation words are vote, elections, president, party, etc., and examples of mobilization words are let's vote, diaspora vote, election stations, etc. Words that do not have political relevance are considered to be neutral.

\section{Moldovan diaspora's social networks and political participation}

A growing number of social networks have been established by Moldovan online. These networks usually associate with the country of origin and the group name many times comprise "Moldovans" followed by the name of the country they stay in, the city, region, and continent (for example Moldovans in Australia, Moldovans in Bilbao, Moldovans in Africa, etc.). Not so frequent are social networks that try to unite all Moldovans abroad regardless of their country of residence, using the names of "Moldovans abroad" or the "Moldovan diaspora" (for example Moldovan Diaspora, Moldovans abroad, the network of Moldovans). Additionally, some social networks try to bind the Moldovan younger generation (for example Moldovan students in Lyon, young Moldovans in Greece) or social networks of Moldovan women (for example The network of active diaspora women from the Republic of Moldova). The description of these social networks altogether with the posts brings evidence on the groups' positive contribution to increasing the diasporas' social capital. Many networks offer access to a wide range of information, starting with employment opportunities, information on local integration policies and laws, transfers of goods and sending money back home and ending some solidarity campaigns.

In an earlier study, Rosca explored the Moldovan diaspora online dialogue and found out that political issues are among the top five arguments discussed by Moldovan diaspora [32]. From one side, it seems that the Moldovan diaspora did not lose their interest in the political situation back home, on the contrary, they seem to access, share information and engage in debates on the political situation, political mobilization, and political participation quite frequently. On the other side, since 2010, the Moldovan political parties started to pay particular interest to Moldovan diaspora, because of diaspora's right to vote abroad, inside the Moldovan embassies and consulates. Such a change triggered both diaspora leaders as well as political parties to try to influence the diaspora decision making, and online platforms and social networks started to be the place of political outreach. In this way, the Moldovan diaspora social networks transcended their initial aim and transformed into a space of political mobilization and participation, bonding and bridging Moldovan diaspora and capitalizing their social capital.

\footnotetext{
${ }^{3}$ The data were exacted as a sovereign action of the authors without the consent of the site or members of the group. Therefore the group members data are anonymous and they cannot be identified in the content of the article.
} 
The diaspora political mobilization culminated with the creation of the social network site AuV which aim and objectives from the start were diaspora political mobilization and participation. Although this is not a novel initiative at the global level (because similar social networks seem to exist from 2012 in Philadelphia, USA), it has been an innovative and powerful political mobilization tool during the presidential elections in 2016 and the following elections. It has to be mentioned that the candidate Maia Sandu (from Party Action and Solidarity - PAS) is a diaspora that returned home and that might be one reason why diaspora showed high solidarity with PAS party. Secondly, Maia Sandu was the first women candidate ever and leading a pro-western party, in addition to her personality assets such as integrity and professionalism.

The NVivo word cloud analysis of the AuV social network online talks proves a highly politicized diasporas' discourse (Figure 1). The interest of diaspora in sharing, posting and debating the political issues from Moldova, in Figure 1, represents a visual representation of the main topics discussed by $\mathrm{AuV}$ social network extracted and elaborated with NVivo. This show, from one side, the hierarchy and trends of political themes among diaspora online debates (for example the political leaders Igor Dodon, Maia Sandu, Andrei Nastase, 2016 presidential elections, etc.) and, from the other side, reveals a direct influence of Moldovan diaspora's online political discourses and their political mobilization and offline political participation.

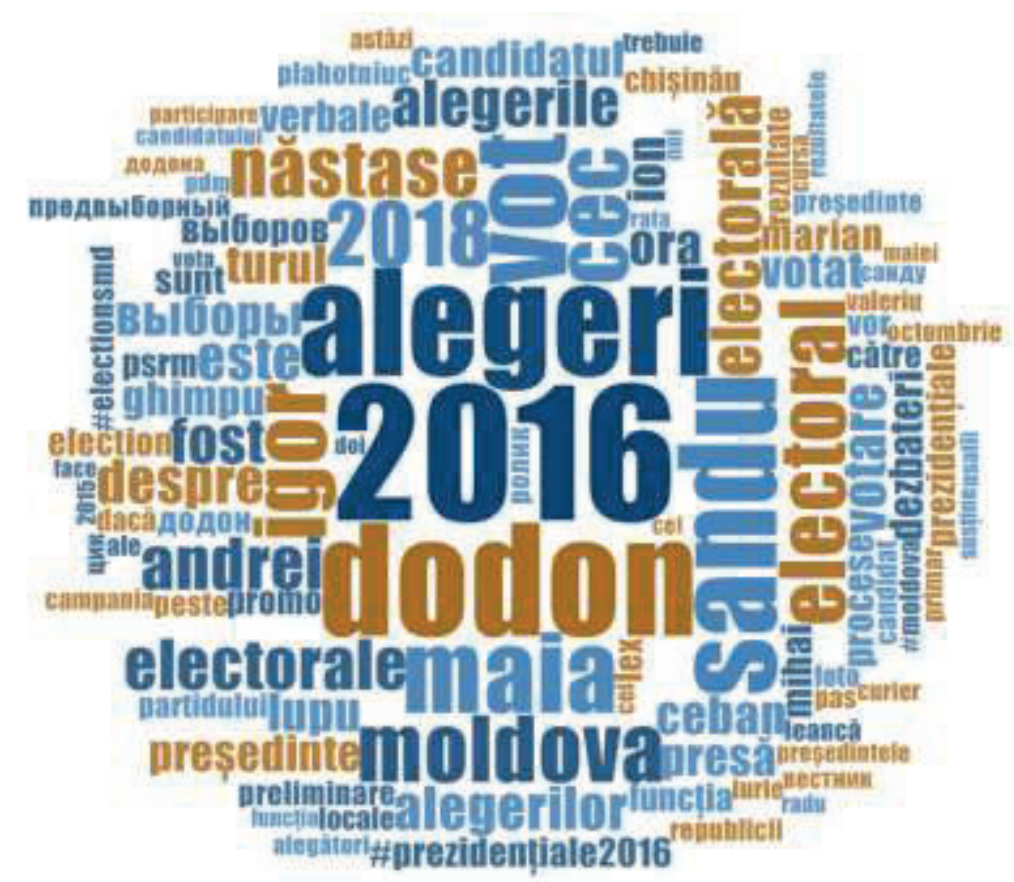

Figure 1: Moldovan Diasporas online discourse

Source: Elaborated by the authors with the data from AuV, extracted in December 2019.

In reference to the presidential election from 2016, some reports qualified the Moldovan diaspora political participation as an "unprecedented presence" [2]. In this way, the social networks managed to mobilize the Moldovan diaspora and increased political participation. This finding is in line with the other studies that have proved the positive correlation between social media and political participation [3]. Thus, the Moldovan diaspora online political discourses associated to a great extent with their political participation.

An important contribution of the AuV seems to be, from one side to capture the previously social networks and sporadic diaspora's political activism and establish for the first time a social network 
with political mobilization and participation aim. According to the final report of Promo Lex, AuV is described as follows "A group of Moldovan citizens living abroad started an online campaign "Adoptă un vot" ("Adopt a vote") to mobilize the Moldovan diaspora. The campaign ensured free transport and accommodation for fellow citizens who wanted to vote in the second round of the presidential election because many citizens had to travel long distances to exercise their right to vote"[30]. After the 2016 presidential elections, the AuV remains an active social network for political mobilization and participation and inspired the creation of other social networks (such as Adopt a Moldovan or Adopt a village) that have a philanthropic aim. The size of the AuV social network is the biggest compared to the other Moldovan diaspora social networks and because of social network particular characteristics, it seems that online platforms enable more effective communication among diaspora with different types of social ties.

The establishment of a social network that aims to political mobilization and participation crystalize a positive influence of social networks with political goals. The voluntary actions that the AuV fostered and successfully delivered inspired not only Moldovan diaspora but also motivated similar actions back home (for example offers for a free ride to students and individuals that otherwise will not go to vote). Consequently, these social ties foster unique routes for engaging in political mobilization and participation actions [5].

The rapid growth of the group members could be explained by the network ties. Each diaspora member, taken separately, possesses a unique and personal social network normally based on strong social ties (friends, relatives, and acquaintances). Thus, we argue that this social network site successfully combines both strong and weak ties in Moldovan diaspora's mobilization and political participation. Consequently, it seems to be efficient at promoting engagement by needed reinforcement, as well as provides good premises at sharing and debating political information.

It is particularly, the "weak" social ties which enable Moldovan diaspora online to increase their social capital and to obtain different types of embedded resources in social networks, and has also a positive influence on their political participation. When Granovetter proposes to revise the network theory he finds out that weak social ties can have an important contribution to social capital growth. The author argues that "while members of one or two cliques may be efficiently recruited, the problem is that, without weak ties, any momentum generated in this way does not spread beyond the clique" [11]. Accordingly, the majority of AuV members might share no ties or some weak ties inside the group but it is particularly these weak ties that manage to access the social benefits that from one side increase their social capital and have a positive impact on diaspora political participation. The posts of hosting and car-sharing as well as bus rides, or collective crowdfunding to rent busses and go to vote are just some proves of the weak social ties impact.

This finding is in line with the research undergone by Keles. The author argues that the internet "contributes to the growth of social networks, social capital, and the community's cultural and political participation" and it encourages subordinated people to participate in civic society and creates a collective source of social capital in the diaspora [18]. The revolutionary importance of the internet, according to the author, is also rooted in its contribution to building social networks that constitute vital resources and different opportunities for Diasporas. In the case of Moldovan diaspora political mobilization, there has not been a vital need for resources but the opportunity to access additional resources generated and available in the $\mathrm{AuV}$ social network had mobilized and positively influenced the diaspora political participation. This is an example of reciprocity and solidarity among Moldovan diaspora and is not a usual happening; on the contrary, it could be labeled as exceptional. Such a state of art points out that Moldovan diaspora, similar to other diaspora groups, has developed 
significant bonding and bridging social capital (strong and weak ties), that helps them consolidate their offline and online resources and generate human, social and economic capitals over time and space [18].

The diaspora social network ties seem to be weak but these ties are vital for diaspora's integration into hosting society and political participation. The weakness of the ties is due to the fact that the $\mathrm{AuV}$ members are globally dispersed and their heterogeneity relates to the origin mainly but their social status seems to be asymmetrical. Some Moldovan diaspora members abroad have a subaltern status, due to the economic and social inequalities while others enjoy a high level of integration and enjoy highly skilled jobs. Thus, the membership in AuV bridges Moldovan diaspora members with different economic and social status for a political goal.

While Moldovan diaspora, for example, has some weak ties within the AuV social network, they seem embedded within each diaspora member's existing set of strong ties of friends and relatives. This offers the possibility of bridging and bonding to other not yet known Moldovan Diasporas. Coser developed a similar argument and he argues that bridging weak ties since they do link different groups, are far more likely than other ties to connect individuals who are significantly different from one another [7]. This point can be clarified by the evidence that AuV social network members are globally dispersed and come together to foster diaspora's political mobilization and participation. Similar to other researches NVivo content analysis to examine political mobilization in AuV finds that online Moldovan diaspora talks keep being linked with offline problems. And the political situation of the country of origin for the Moldovan diaspora seems to still be an important topic and preoccupy them to quite a high extent. The NVivo summary report, with the option of grouping, reveals the main codes of political interest back home.

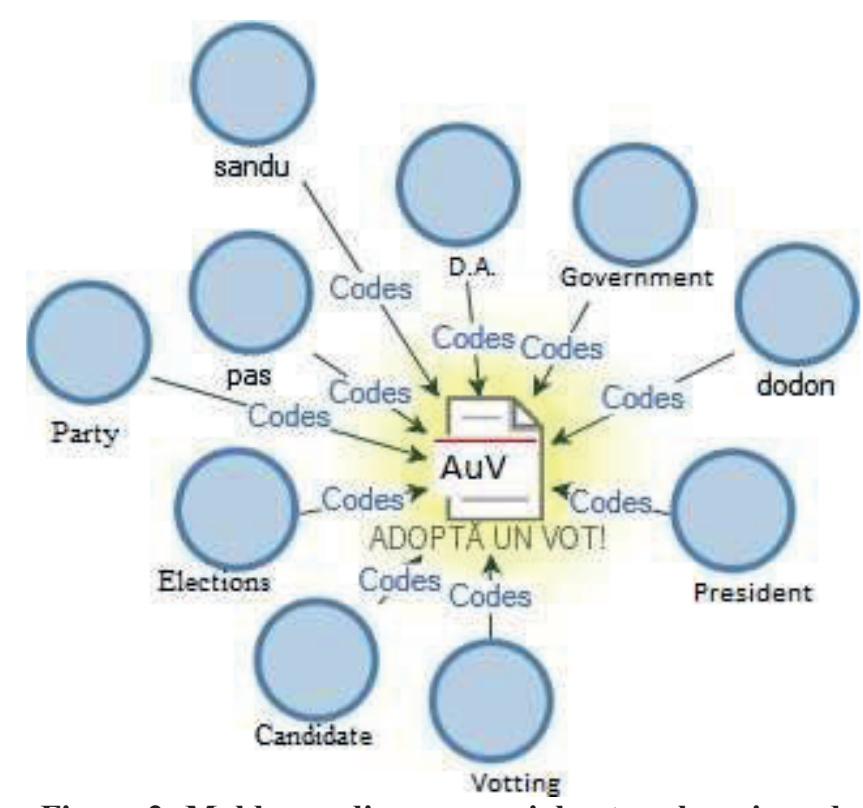

Figure 2: Moldovan diaspora social network main codes Source: Elaborated by the authors.

As the social network has been established during the presidential election of 2016 the main codes are related to the two candidates: Sandu and Dodon. Additionally, a high presence of Moldovan diaspora online talks is in support of two pro-European parties: PAS and DA. The election results confirm that the Moldovan diaspora voted for the coalition of these two parties. Thus, it can be argued that social network characteristics correlate positively with diaspora political mobilization and 
participation. Additionally, these networks contribute to the increase of diaspora social capital. During the elections, Moldovan diaspora shared their homes and offered free rides to the election spot to other Moldovans and established friendships and future initiatives. The off-line sessions organized by $\mathrm{AuV}$ administrators and moderator both outside and inside of Moldova that consequently led to other actions are just an example.

$\mathrm{AuV}$ is a heterogeneous social network and all members are Moldovans sharing the same cultural, historical, and social interest. Nevertheless, some asymmetries can be identified in linguistic and identity fields. Some prefer Russian, some Romanian and other Moldovan language and identity. On top of this, the heterogeneity of the social network seems to be an interest in some pro-European parties (PAS, DA) whiles a negative discourse persists about the pro-Russian party (PSRM) and oligarch Moldovan Democratic Party. In this way, the Moldovan diaspora political mobilization and participation are moderated to a great extent by the social network heterogeneity in regards to political party preferences. This finding is in line with Campbell and Kwak's research that reveals that online diaspora discourse is positively associated with political participation, but that this relationship is moderated by the size and heterogeneity of one's network. Additionally, the authors argue that diaspora participation increases in large networks of like-minded individuals, but declines inside the homogeneous networks that are small [5]. This seems to be the case of AuV social network where the big majority support a particular party, come from the same country and united together to foster political mobilization and participation.

\section{Conclusions and future research implications}

Drawing upon the existent literature, this article considered the social capital framework to analyze the Moldovan diaspora's social networks and tested its influence on diaspora mobilization and political participation.

Two main findings are concluded from the empirical analysis of the AuV social network. First of all, this study explores the relationship between the Moldovan diaspora online political discourses and their political mobilization and participation. As a result, the study finds out that online interactivity and debates among $\mathrm{AuV}$ Moldoval diaspora social network members are highly politicized. Consequently, more political information is discussed and shared, altogether with the alternative and non-censured information available online foster a better understanding of political issues back home. Accordingly, more talks and debates on political issues online positively influence diaspora political mobilization and participation. Additionally, social interaction and shared understanding among AuV diaspora social network members online seem to increase because the platform enables members to comment freely, interact and receive immediate feedback from the network's diaspora members.

Secondly, this study examines the Moldovan Diaspora Social Networks' characteristic (size, heterogeneity, and social ties) influence on political mobilization and participation. Our empirical results demonstrate that the $\mathrm{AuV}$ Moldovan diaspora social network was established and function mainly via social ties. In AuV one can identify three types of ties: strong (e.g. family, close friends), weak (e.g. ex-colleagues, neighbors, schoolmates, etc.) and no ties (members of the same group without really knowing each other). However, the research did not have any information on what kind types members have in AuV, but most probably no ties must be the most common. Nevertheless, the $\mathrm{AuV}$ no ties and weak social ties heavily rely on each member's strong social ties. Consequently, it is an example of a successful combination of no ties, weak and strong ties and a positive contribution toward political mobilization and participation. Additionally, the results prove a positive influence of the size and heterogeneity of AuV social network on political mobilization and participation. 
Therefore, results reveal the Moldovan diaspora's strong interest in politics back home, and a positive correlation between the social network's political mobilization and participation. The link between Moldovan diaspora mobilization and political participation is explained by the characteristics of the social network within which diaspora participate and communicate. Additionally, the social networks' power to mobilize the Moldovan diaspora political participation is moderated by the size, heterogeneity, and ties of the diaspora's social network. Therefore, political participation seems to increases within large social networks of like-minded individuals.

For theoretical implications, this study makes at least one major contribution to the extant literature. The study contributes to filling in the research gap on Moldovan diaspora online social networks and political mobilization and participation from a social capital theoretical perspective. Previous literature in this area mostly focused on Moldovan diaspora dialogue online [32], while the influence of social capital on political mobilization and participation was ignored. Additionally, the research findings are consistent with the previous empirical analysis of social capital, diaspora participation, and online social networks.

In spite of this, further studies are necessary to test the data and analyze the Moldovan social network's interest in political issues and as well as test the potential for political mobilization and participation in future election campaigns. Moldovans abroad are globally dispersed, thus the online social network might be the only source of contact with the political parties back home. Due to this, the online social networks of the Moldovan diaspora can play an active role in future political mobilization and participation campaigns.

\section{References}

[1] AlOnSO, A. and OIARZABAL, P. J., Diasporas in the New Media Age. Identity, Politics and Community., University of Nevada Press, Nevada, 2010.

[2] BERLINSCHII, C., Alegerile prezidențiale 2016 - prezență la vot fără precedent a diasporei Republicii Moldova, Chisinau, 2016.

[3] BOULIANNE, S., Social media use and participation: a meta-analysis of current research, Information, Commun. Soc. 18 (2015) 524-538.

[4] BOURDIEU, P., The Forms of Capital, in: J.Richardson (Ed.), Handb. Theory Res. Sociol. Educ., Greenwood, New York, 1986: pp. 46-58.

[5] CAMPBELL, S. W. and KWAK, N., Political Involvement in "Mobilized" Society: The Interactive Relationships Among Mobile Communication, Network Characteristics, and Political Participation, J. Commun. 61 (2011) 1005-1024.

[6] COLEMAN, J. S., Social Capital in the Creation of Human Capital, Am. J. Sociol. 94 (1988) 95-120.

[7] COSER, L. A., The Idea of Social Structure : Papers in Honor of Robert K. Merton, Routledge, New York, 2012.

[8] EREL, U., Migrating Cultural Capital: Bourdieu in Migration Studies, Sociology. 44 (2010) 642-660. 
[9] EVELAND, W. P. and HIVELY, M. H., Political discussion frequency, network size, and "heterogeneity" of discussion as predictors of political knowledge and participation., J. Commun. 59 (2009) 205-224.

[10] GIL DE ZÚÑIGA, H., JUNG, N. and VALENZUELA, S., Social Media Use for News and Individuals' Social Capital, Civic Engagement and Political Participation, J. Comput. Commun. 17 (2012) 319-336.

[11] GRANOVETTER, M., The Strength of Weak Ties: A Network Theory Revisited, Sociol. Theory. 1 (1983) 201-233.

[12] HALPERN, D., VALENZUELA, S. and KATZ, J. E., We Face, I Tweet: How Different Social Media Influence Political Participation through Collective and Internal Efficacy, J. Comput. Commun. 22 (2017) 320-336.

[13] HAMPTON, K. N. and LING, R., Explaining communication displacement and large-scale social change in core networks, Information, Commun. Soc. 16 (2013) 561-589.

[14] HARDY, B. W. and SCHEUFELE, D. A., New Media and Democratic Citizenship, in: A.-V. Anttiroiko (Ed.), Electron. Gov. Concepts, Methodol. Tools, Appl., IGI Global, Hershey and New York, (2008) 4029-4036.

[15] JACKSON, K. and BAZELEY, P., Qualitative Data Analysis with NVivo, 3rd ed., Sage Publications Ltd, London and New York, 2019.

[16] JOHNSTON, K., TANNER, M., LALLA, N. and KAWALSKI, D., Social capital: The benefit of Facebook friends, Behav. Inf. Technol. 32 (2013) 24-36.

[17] KATZ, E., Introduction: The state of the art., in: T.L. Glasser, C.T. Salmon (Eds.), Public Opin. Commun. Consent, Guilford Press, New York, 1994: p. 475.

[18] KELES, J. Y., Digital Diaspora and Social Capital, Middle East J. Cult. Commun. 9 (2016) $315-333$.

[19] KEN'ICHI, I. and RICHEY, S. E., Japanese Network Capital: The impact of social networks on Japanese political participation., Polit. Behav. 27 (2005) 239-260.

[20] KIM, Y. and CHEN, H. -T., Discussion Network Heterogeneity Matters: Examining a Moderated Mediation Model of Social Media Use and Civic Engagement, Int. J. Commun. 9 (2015) 2344-2365.

[21] KITTS, J. A., Mobilizing black boxes: social networks and participation in social movement organizations., Mobilization An Int. J. 5 (2000) 241-257.

[22] KOK, S. and ROGERS, R., Rethinking migration in the digital age: transglocalization and the Somali diaspora, Glob. Networks. 17 (2017) 23-46. 
[23] KWAK, N., WILliAMS, A. E., WANG, X. and LEE, H., Talking politics and engaging politics: An examination of the interactive relationships between structural features of political talk and discussion engagement., Communic. Res. 32 (2005) 87-111.

[24] LANCEE, B., Immigrant performance in the labour market: bonding and bridging social capital, Amsterdam University Press, Amsterdam, 2012.

[25] LIN, N., Building a Network Theory of Social Capital', CONNECTIONS. 22 (1999) 28-51.

[26] LING, R. S., New tech, new ties : how mobile communication is reshaping social cohesion., MIT Press, Cambridge, 2008.

[27] NAHAPIET, J. and GHOSHAL, S., Social Capital, Intellectual Capital, and the Creation of Value in Firms., Acad. Manag. Proc. (1997) 35-39.

[28] PAN, Z., SHEN, L., PAEK, H. -J. and SUN, Y., Mobilizing Political Talk in a Presidential Campaign, Communic. Res. 33 (2006) 315-345.

[29] PORTES, A., Social Capital: Its Origins and Applications in Modern Sociology, Annu. Rev. 24 (1998) 1-24.

[30] PROMO-LEX, Observation Mission for the Presidential Election in the Republic of Moldova on 30 October 2016, Chisinau, 2017.

[31] PUTNAM, R. D., Bowling Alone: America's Declining Social Capital, Cult. Polit. (2000) 223234.

[32] ROSCA, M., Configurarea dialogului cultural în societățile de adopție a migranților., History Institute, 2018.

[33] SHAH, D. V., KWAK, N. and HOLBERT, R. L., "Connecting” and "disconnecting" with civic life: Patterns of internet use and the production of social capital, Polit. Commun. 18 (2001) $141-162$.

[34] VALENZUELA, S., CORREA, T. and GIL DE ZÚÑIGA, H., Ties, Likes, and Tweets: Using Strong and Weak Ties to Explain Differences in Protest Participation Across Facebook and Twitter Use, Polit. Commun. 35 (2018) 117-134. 